\title{
Assessment of data uncertainty and plausibility over the Nam Co Region, Tibet
}

\author{
S. Biskop ${ }^{1}$, P. Krause ${ }^{1}$, J. Helmschrot ${ }^{1,2}$, M. Fink ${ }^{1}$, and W.-A. Flügel ${ }^{1}$ \\ ${ }^{1}$ Department for Geoinformatics, Hydrology and Modelling, Friedrich-Schiller-University, Jena, Germany \\ ${ }^{2}$ Department of Civil and Environmental Engineering, University of Washington, Seattle, USA
}

Correspondence to: S. Biskop (c2biso@uni-jena.de)

\begin{abstract}
One of the major challenges for water balance studies in the remote and mostly ungauged region of the Tibetan Plateau is the lack of suitable and reliable climate data to drive hydrological models. Ground observations are rare in the high-mountainous region of the Nam Co basin and only global and regional gridded climate products are available as model input data, but these data sets need to be carefully analysed if used as driving force for hydrological modelling. In this study, various global and regional gridded data products for temperature and precipitation were compared to assess spatio-temporal deviations between several data sets. For the comparison absolute and relative differences of annual and seasonal long-term means were calculated. Climatic trends were analysed by using the non-parametric MannKendall trend test. In addition, gridded climate data sets were compared to meteorological observations in order to evaluate their plausibility. The comparative statistical analysis showed significant differences in the magnitude, the seasonality, the spatial pattern and the trend behaviour of the analysed climate variables, in particular for precipitation data. The identified inconsistencies underpin the necessity to quantify the uncertainty of such climate data. Moreover, the presented study highlights the importance of further research efforts to develop regional climate data sets with finer resolutions to reduce the model's uncertainty resulting from climate input data. Such higher resolution is needed for a sufficient representation of regional topographic and orographic effects in order to simulate important hydrological processes in mountainous areas like snow accumulation and melting.
\end{abstract}

\section{Introduction}

As stated in many studies, the Tibetan Plateau is considered as one of the most vulnerable regions on earth with regard to the impact of global climate change (Eriksson et al., 2009; Kang et al., 2010). The numerous endorheic lakes on the high elevation plateau are often referred to as sensitive indicators of the effect of changing climate on the hydrology of the Tibetan Plateau (Bian et al., 2009; Ding et al., 2006). Lake level fluctuations indicate changes in the regional water balance mostly attributed to changing precipitation amount and distribution, changing evapotranspiration rates and increased glacier melt runoff (Krause et al., 2010; Lu et al., 2005; Wu and Zhu, 2008; Yao et al., 2010; Ye et al., 2008). The glacier-fed lake Nam Co $\left(30^{\circ} \mathrm{N} / 90^{\circ} \mathrm{E}, 4718 \mathrm{~m}\right.$ a.s.l., $2000 \mathrm{~km}^{2}$ ) showed a noticeable increase in area, volume and lake level over the last decades (Kropacek et al., 2011; Liu et al., 2010; Zhu et al., 2010). This in turn indicates that the Nam Co basin $\left(10800 \mathrm{~km}^{2}\right)$, located at the foot of the western Nyainqentanglha Mountains in the southern central part of the Tibetan Plateau, is experiencing changes in the hydrological dynamics. Those changes need to be investigated to gain a better understanding about the interactions between hydrological and climatic processes, and also to detect the hydrological key components and processes mainly influencing the considerable increase in lake volume. For the quantification of the various sources contributing to the lake level rise, a calculation of the water amount circulating in the hydrological system is required by simulating or modelling the underlying hydrological processes and components (Krause et al., 2010). The accurate quantification of all water balance components as well as climate impacts based on hydrological modelling depends on the quality and quantity of available meteorological input data. Climate-related model input data forcing hydrological models are recognized as a critical 


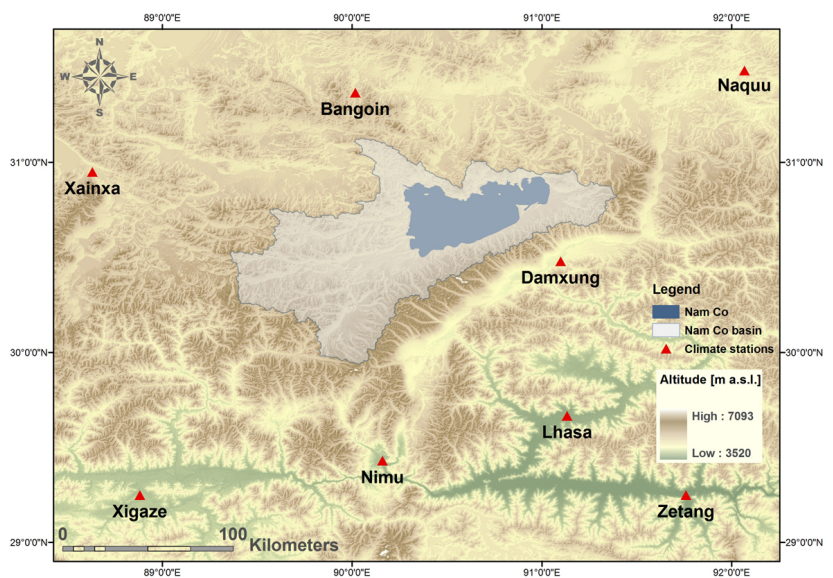

Fig. 1. Location of climate stations surrounding the Nam Co basin.

factor controlling the uncertainty of the model performance (Gourley and Vieux, 2006).

As presented in Fig. 1, meteorological observation data are very limited in the region of Nam Co, which is a general problem throughout the high-altitude Tibetan Plateau. Therefore, current hydrological modelling applications of Tibetan Plateau basins primarily rely on gridded climate data sets (Krause et al., 2010; Prasch et al., 2011). Since global and regional gridded data sets are based on the analysis and processing of data from various sources such as ground observation, satellite estimates and climate model simulations, differences in quality and quantity can be expected. The uncertainty of existing gridded precipitation data sets and the impact on runoff estimates has been shown and discussed in detail by Fekete and Vörösmarty (2003). Primarily in semiarid regions, precipitation inaccuracy causes even greater uncertainty of model response (Fekete and Vörösmarty, 2003).

Besides precipitation, temperature is one of the most important input variables for hydrological modelling, thus temperature and precipitation time series of selected global and regional gridded climate data sets were compared to quantify the degree of discrepancy between them and to evaluate their suitability as driving forces for distributed hydrological modelling of Tibetan Plateau basins. The comparison was carried out for an area with the extent of $29.5^{\circ} \mathrm{N}, 89.0^{\circ} \mathrm{E}-31.5^{\circ} \mathrm{N}$, $91.5^{\circ} \mathrm{E}$ covering the Nam Co catchment and its surrounding area.

\section{Data and methods}

The data evaluation of this study comprises the statistical analysis of temperature and precipitation time series from ground-based measurements (Table 1) and gridded global and regional climate data sets (Table 2).

As shown in Fig. 1, there is no meteorological station with long-term measurements located within the Nam Co basin. Meteorological stations surrounding the Nam Co basin (Ta- ble 1) are sparsely distributed and situated in lower altitudes $(<4800 \mathrm{~m}$ a.s.l.) mainly south of the Nyainqentanghla Mountains (reaching elevations over $7100 \mathrm{~m}$ a.s.l.) located along the southern borderline of Nam Co basin. Since all selected stations provide time series of temperature and precipitation between 1981 and 2004 without large data gaps, this period was chosen for the statistical analysis.

As listed in Table 2, the compared global and regional gridded climate data products differ in terms of temporal coverage, spatial and temporal resolutions as well as the availability of temperature and precipitation data. Data from the global circulation model (GCM) ECHAM5 with a spatial resolution of $1.9^{\circ}$ were dynamically downscaled to a resolution of $0.5^{\circ}$ by applying the regional climate model COSMOCLM (http://www.clm-community.eu/) for the South Asia region (Dobler et al., 2011). The generated COSMO-CLM ECHAM5 product will be referred to as ECHAM5 in the following sections. The CRU data set was developed by the Climate Research Unit at the University of East Anglia by using an interpolation approach including collected station data from various sources (Mitchell and Jones, 2005). The regional rain-gauge based precipitation product APHRODITE (Asian Precipitation - Highly-Resolved Observational Data Integration towards Evaluation of Water Resources) was developed by the Research Institute for Humanity and Nature (RIHN) and the Meteorological Research Institute of Japan Meteorological Agency (MRI/JMA) (Yatagai et al., 2009). The Tropical Rainfall Measuring Mission (TRMM) is a joint endeavour between the NASA and Japan's National Space Development Agency to provide precipitation data for tropical and subtropical regions. Details of the various satellitebased precipitation products of TRMM are given by Huffmann et al. (2007).

The data evaluation of this study was carried out by the following two steps:

i) Analysis of in-situ measurements to assess the spatiotemporal climatic variability of the Nam Co region.

Spatio-temporally varying climate conditions of meteorological observations were analysed based on calculated annual and seasonal means of temperature and precipitation data for hydrological years from November to October. For climatic trend detection the Mann-Kendall non-parametric trend test (Mann, 1945; Kendall, 1975) was applied to the 24-years period from 1981 to 2004. Non-parametric tests are designed to identify trends in time series, rather than the magnitude (Hipel and McLeod, 2005). The Mann-Kendall trend test provides statistical significance levels evaluating the probability whether a linear or non-linear trend exists. In the presented study, a trend is defined as significant at the significance level of $80 \%$, whereas a trend is considered as highly significant at the $95 \%$ significance level. If the significance level is lower than $80 \%$, the trend is assumed to be not significant. A detailed description of the Mann-Kendall 
Table 1. Meteorological stations surrounding Nam Co basin.

\begin{tabular}{lcccl}
\hline Meteorological Station & Longitude $(\mathrm{E})$ & Latitude $(\mathrm{N})$ & Altitude $(\mathrm{m})$ & Institution* \\
\hline Xainxa & 88.63 & 30.95 & 4670 & NOAA/NCDC \\
Bangoin & 90.02 & 31.37 & 4701 & NOAA/NCDC \\
Naquu & 92.07 & 31.48 & 4508 & NOAA/NCDC \\
Damxung & 91.1 & 30.48 & 4200 & ICIMOD \\
Zetang & 91.76 & 29.25 & 3552 & ICIMOD \\
Lhasa & 91.13 & 29.67 & 3650 & NOAA/NCDC \\
Nimu & 90.16 & 29.43 & 3809 & ICIMOD \\
Xigaze & 88.88 & 29.25 & 3837 & NOAA/NCDC \\
\hline
\end{tabular}

* NOAA/NCDC $=$ National Oceanic and Atmospheric Adminstration/National Climatic Data Center; ICIMOD = International Centre for Integrated Mountain Development

Table 2. Summary of global and regional gridded climate data time series used in this study.

\begin{tabular}{lllll}
\hline Data set & Space & Time step & Time period & Climate variable \\
\hline COSMO-CLM ECHAM5 & $0.5^{\circ}$ & daily & $\begin{array}{l}\text { 1960-2000 } \\
\text { scenarios up to 2080 }\end{array}$ & temperature, precipitation \\
CRU TS3.0 & $0.5^{\circ}$ & monthly & $\begin{array}{l}\text { 1901-2006 } \\
\text { scenarios up to 2100 }\end{array}$ & temperature, precipitation \\
& & & $1951-2007$ & precipitation \\
APHRODITE V1003R1 & $0.5^{\circ}, 0.25^{\circ}$ & daily & precipitation \\
TRMM 3B43 & $0.25^{\circ}$ & monthly & $1999-2008$ & \\
\hline
\end{tabular}

test is given by Burn and Elnur (2002).

ii) Comparison between various gridded climate data and against ground observations to detect spatial and temporal deviations.

The data sets ECHAM5, CRU and APHRODITE were compared for the study time period (1981-2004) with a resolution of $0.5^{\circ} \times 0.5^{\circ}$ which divides the study area $\left(29.5^{\circ} \mathrm{N}\right.$, $89.0^{\circ} \mathrm{E}-31.5^{\circ} \mathrm{N}, 91.5^{\circ} \mathrm{E}$ ) into 20 grid cells. In addition, APHRODITE and TRMM precipitation data were compared based on a $0.25^{\circ}$ latitude-longitude resolution representing 140 grid cells for the entire study area. Due to the different temporal coverage of APHRODITE and TRMM the comparison was carried out for the period from 1999-2007, which was completely covered by both data sets.

To compare several data sets, absolute and relative differences of annual and seasonal means of temperature and precipitation data were calculated for individual grid cells and spatial averaged for the entire study area. For the one-toone grid comparison, deviations between corresponding grid cells were analysed based on the frequency distribution of the absolute and relative difference values. Moreover, available time series of ECHAM5, CRU and APHRODITE were also examined regarding trends by applying the Mann-Kendall trend test.

As each cell of gridded data sets represents an integrated value for an area of either $0.5^{\circ}$ or $0.25^{\circ}$ in square, their absolute values cannot be directly compared with data received from a specific ground station which only represents one point within the grid cell. Especially in mountainous or alpine regions, point measurements can vary significantly within short distances because of changes in elevation and orographic effects. However, gridded climate data can be checked against ground observation data in respect of the temporal variability. Thus, the agreement of the annual cycle between data from individual grid cells and station data was estimated by correlation analysis and quantified with the coefficient of determination. Furthermore, gridded climate data were controlled regarding significant trends of climate variables which were identified in time series from several ground stations.

\section{Results and discussion}

\subsection{Analysis of observation data}

The results of the statistical analyses of temperature and precipitation in-situ measurements are summarised in Tables 3 and 4. The mean temperature for the time period 1981 to 2004 ranges from around $9{ }^{\circ} \mathrm{C}$ in the southern part with lower elevations down to around $0^{\circ} \mathrm{C}$ in the Nam Co region north of the Nyainqentanglha Mountains which generally shows lower temperatures because of the higher elevation (Tables 1 and 3). Stations in the eastern and southern area (Naqu, Damxung, Lhasa, Zetang, Nimu, Xigaze) receive about $450 \mathrm{~mm}$ precipitation per year, mainly occurring during the monsoon season (June-September). In contrast, the stations Xainxa and Bangoin in the upper northwestern part 
Table 3. Annual and seasonal means of temperature and precipitation measurements for the time period 1981-2004.

\begin{tabular}{lcccccc}
\hline \multirow{3}{*}{ Station } & \multicolumn{5}{c}{ Annual/seasonal mean (1981-2004) } \\
\cline { 2 - 6 } & \multicolumn{3}{c}{ Temperature [ $\left.{ }^{\circ} \mathrm{C}\right]$} & \multicolumn{3}{c}{ Precipitation [mm] } \\
\cline { 2 - 7 } & Annual & Nov-Apr & May-Oct & Annual & Nov-Apr & May-Oct \\
\hline Xainxa & 0.6 & -5.7 & 6.8 & 356 & 19 & 337 \\
Bangoin & -0.1 & -6.3 & 6.0 & 372 & 24 & 348 \\
Naquu & -0.6 & -7.3 & 6.1 & 482 & 40 & 442 \\
Damxung & 1.8 & -4.4 & 8.1 & 541 & 37 & 504 \\
Zetang & 8.9 & 3.7 & 14.1 & 464 & 27 & 436 \\
Lhasa & 8.5 & 3.1 & 13.8 & 455 & 18 & 437 \\
Nimu & 7.0 & 1.4 & 12.7 & 408 & 14 & 394 \\
Xigaze & 7.1 & 1.6 & 12.5 & 476 & 12 & 464 \\
\hline
\end{tabular}

Table 4. Mann-Kendall trend test results for temperature and precipitation measurements over 24yr-period 1981-2004.

\begin{tabular}{|c|c|c|c|c|c|c|}
\hline \multirow{3}{*}{ Station } & \multicolumn{6}{|c|}{ Mann-Kendall trend test for 1981-2004 (+/+ significant $p=80 \% /$ highly significant $p=95 \%)$} \\
\hline & \multicolumn{3}{|c|}{ Temperature } & \multicolumn{3}{|c|}{ Precipitation } \\
\hline & Year & Nov-Apr & May-Oct & Year & Nov-Apr & May-Oct \\
\hline Xainxa & + & + & no & no & + & no \\
\hline Bangoin & + & + & + & no & no & no \\
\hline Naquu & + & + & + & + & + & + \\
\hline Damxung & + & + & no & + & no & + \\
\hline Zetang & + & + & no & + & + & + \\
\hline Lhasa & + & + & + & + & no & + \\
\hline Nimu & + & + & no & + & no & + \\
\hline Xigaze & + & + & no & no & no & no \\
\hline
\end{tabular}

show a lower average annual precipitation amount of around $350 \mathrm{~mm}$ (Table 3), because both stations are located in the rain shadow of the southwest-northeast striking Nyainqentanglha Mountains which act as barrier when the monsoon coming from southeast advances to the northwest. This is in accordance with the climate classification by the Chinese Academy of Sciences (CAS) (1984) which refers the region north of Nyainqentanglha as belonging to the subfrigid zone (MAT $<0^{\circ} \mathrm{C}$ ) and the area south of the Mountains to the temperate zone (MAT $\approx 0-8{ }^{\circ} \mathrm{C}$ ). With regard to the humidity, the study region is mainly classified as semi-arid climate (MAP $\approx 300-450 \mathrm{~mm}$ ), whereby the eastern part is characterized by semi-moist conditions (MAP $\approx 400-550 \mathrm{~mm}$ ). A more detailed description of the spatial pattern of climatic conditions in this region is given by Leber et al. (1995).

The differences of temperature and precipitation between summer and winter show a magnitude of $10^{\circ} \mathrm{C}$ to $13^{\circ} \mathrm{C}$ and $300 \mathrm{~mm}$ to $500 \mathrm{~mm}$ at the various stations (Table 3 ). This indicates a clear seasonal variability which is greater than the spatial variation of the mean annual temperature and precipitation distribution. In addition, precipitation amounts show a strong interannual variability.

The trend analysis for temperature and precipitation (Table 4) shows significant trends depending on region and season. The positive temperature trend, which is particularly strong in the southern part, is of higher significance $(p=95 \%)$ in the winter season. This indicates that climate warming is supposed to cause a strong upward trend in winter temperature in this region. Contrary to the temperature trend analysis, the evaluation of precipitation trends does not show a general trend for all stations (Table 4). An increasing precipitation trend, in particular highly significant $(p=95 \%)$ during the monsoon season, could be detected for stations located in the eastern and southern study area. The spatial pattern of the generally increasing tendency of summer precipitation in the eastern and southern part indicates a stronger influence of the summer monsoon in this area.

\subsection{Comparison of gridded climate data sets}

\subsubsection{Temperature}

The comparison of the spatially averaged annual and seasonal mean temperature of ECHAM5 (annual: $-0.8^{\circ} \mathrm{C}$, winter: $-7.1{ }^{\circ} \mathrm{C}$, summer: $5.3^{\circ} \mathrm{C}$ ) and $\mathrm{CRU}$ (annual: $-0.7^{\circ} \mathrm{C}$, winter: $-6.9^{\circ} \mathrm{C}$, summer: $5.6^{\circ} \mathrm{C}$ ) show relatively low values for mean absolute and relative differences (Table 5). This suggests that these two data sets are in good agreement con- 
Table 5. Statistical analysis results for temperature data of ECHAM5 and CRU for the period 1981-2004.

\begin{tabular}{lcccccc}
\hline \multirow{3}{*}{ Mean } & \multicolumn{5}{c}{ Temperature $\left[{ }^{\circ} \mathrm{C}\right]$} \\
\cline { 2 - 6 } & \multicolumn{5}{c}{ ECHAM5 } \\
\cline { 2 - 6 } & Annual & Nov-Apr & May-Oct & Annual & Nov-Apr & May-Oct \\
\cline { 2 - 6 } & -0.8 & -7.1 & 5.3 & -0.7 & -6.9 & 5.6 \\
\hline \multirow{2}{*}{ Mean Difference } & Annual & ECHAM5 - CRU & Nov-Apr & May-Oct \\
\cline { 2 - 6 } & 0.2 & 0.2 & 0.3 \\
\hline Absolute difference & 0.2 & 0.03 & 0.05 \\
\hline Relative difference & & & & \\
\hline
\end{tabular}

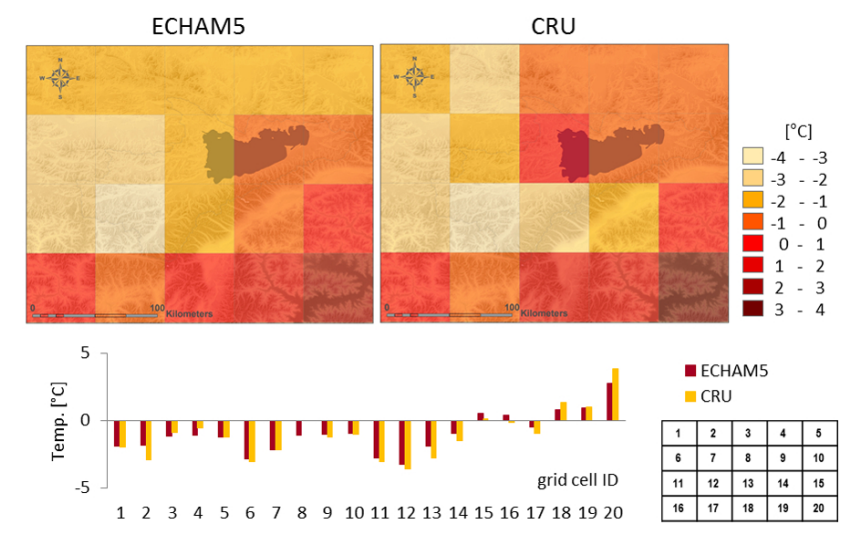

Fig. 2. Comparison of annual mean temperature data of ECHAM5 and CRU for the period 1981-2004.

cerning temperature range and seasonality. The correlation analysis between gridded data sets and station data values for the mean inner annual variations showed that both ECHAM5 and CRU mean monthly temperature data match with measured data $\left(r_{\mathrm{ECHAM} 5}=0.99, r_{\mathrm{CRU}}=0.99\right)$.

The gridded average temperature data of ECHAM5 and CRU show a similar regional distribution as classified by Leber et al. (1995), i.e. higher temperatures in the southern part of the region with lower elevations and lower temperatures north of the Nyainqentanglha Mountains (Fig. 2). The colder climate conditions over the Nyainqentanglha Mountains are not represented due to the coarse grid resolution. The frequency distribution of the mean absolute difference indicates that most of the grid cells exhibit a difference of less than $0.5^{\circ} \mathrm{C}$ (Fig. 3). However, the one-to-one grid comparison also shows local deviations of up to $1.5^{\circ} \mathrm{C}$.

In Fig. 4, CRU temperature data show an increasing trend for all grid cells which is significant $(p=80 \%)$ in the summer period and highly significant $(p=95 \%)$ in the winter period and corresponds to trends identified in data from ground observations. The trend analysis of ECHAM5 reveals a less clear pattern with significant $(p=80 \%)$ and highly significant $(p=95 \%)$ increasing trends in $65 \%$ of the study

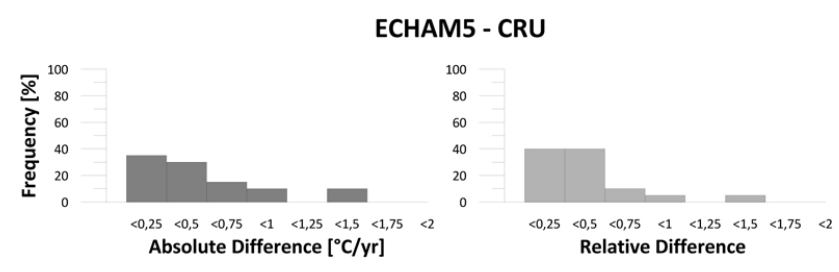

Fig. 3. Frequency distribution of absolute and relative differences in mean temperature of from ECHAM5 and CRU for the period 1981-2004.
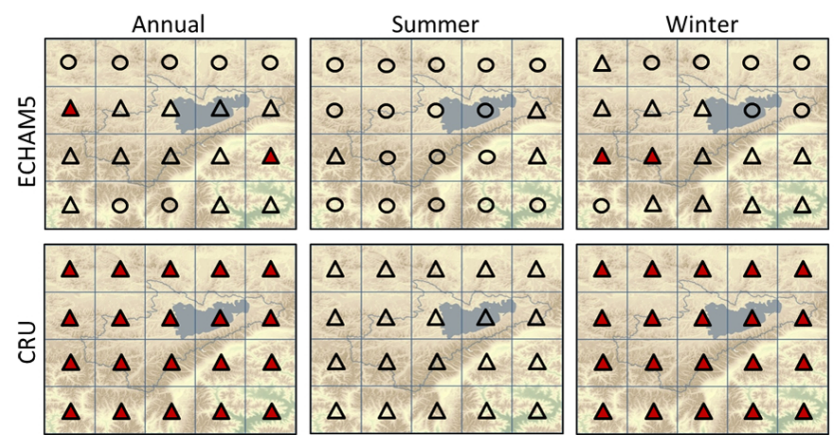

Fig. 4. Mann-Kendall trend test results for annual, summer and winter temperature of ECHAM5 (top) and CRU (bottom) for the period 1981-2004 $(\triangle /$ red $\triangle=$ significant/highly significant increasing trend with $p=80 \% / 95 \% ; \bigcirc=$ no significant trend).

region throughout the whole year and winter season. For the summer period no significant trend was found in most grid cells (Fig. 4).

\subsubsection{Precipitation}

\section{Comparison between ECHAM5, CRU and APHRODITE for 1981-2004}

The annual mean precipitation sum of ECHAM5 $(661 \mathrm{~mm})$ for the entire region is $80 \mathrm{~mm}$, i.e. $12 \%$, higher than the annual mean precipitation sum of CRU $(581 \mathrm{~mm})$ (Table 6). As shown in Table 6, the APHRODITE precipitation prod- 


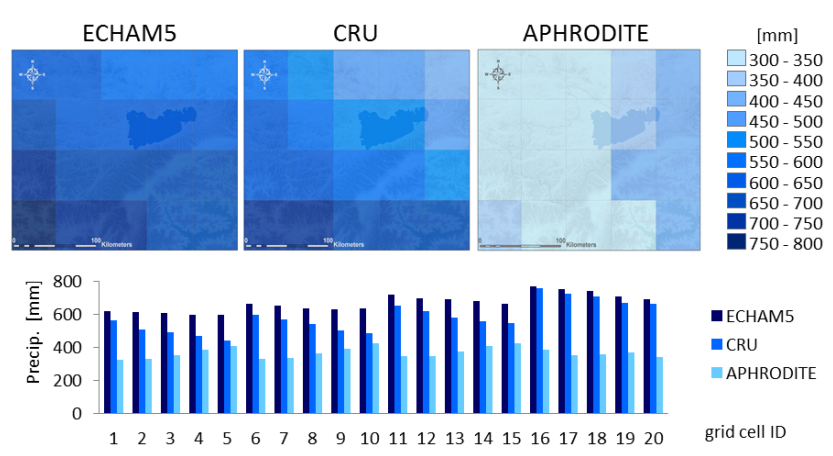

Fig. 5. Comparison of annual mean precipitation data of ECHAM5, CRU and APHRODITE for the period 1981-2004.

uct shows a much lower annual mean sum resulting in high mean absolute and relative differences when compared to the CRU and ECHAM5 data sets. The annual mean precipitation of APHRODITE with $359 \mathrm{~mm}$ is around $46 \%$ lower than ECHAM5 and about $38 \%$ lower than CRU.

The analysis of the seasonal variations of precipitation amounts indicates distinct differences between all data sets, particularly for the dry winter season. Comparing ECHAM5 and CRU, the mean absolute difference of $33 \mathrm{~mm}$ for the summer season is equivalent to a relative difference of 0.06 , while the mean absolute difference of $50 \mathrm{~mm}$ in the winter period corresponds to a relative difference of 0.67 (Table 6). Therewith, the ECHAM5 data set shows an amount of winter precipitation which is $70 \%$ larger than the amount received from CRU data. The mean absolute difference between ECHAM5 and APHRODITE is higher for the summer period $(241 \mathrm{~mm})$ and lower in winter $(59 \mathrm{~mm})$ whereas the relative difference shows an opposite pattern with a larger difference in winter (0.76) and a lower value in summer (0.41). The comparison of CRU and APHRODITE shows higher absolute and relative mean seasonal differences for summer $(215 \mathrm{~mm}, 0.39)$ than for winter months $(7 \mathrm{~mm}, 0.28)$ (Table 6).

By comparing mean monthly precipitation data of ECHAM5, CRU and APHRODITE with station data, APHRODITE shows a high correlation with the measured annual cycle $\left(r_{\text {APHRODITE }}=0.99\right)$, while the correlations of $\mathrm{CRU}\left(r_{\mathrm{CRU}}=0.96\right)$ and ECHAM5 $\left(r_{\mathrm{ECHAM}}=0.94\right)$ are slightly lower.

As presented in Fig. 5, ECHAM5 and CRU data show a similar distribution with a decrease from southwest to northeast whereas APHRODITE exhibits a contrary pattern with a precipitation decrease from southeast to northwest. According to the spatial large-scale pattern discussed by Leber et al. (1995), APHRODITE reveals a more realistic spatial distribution. The one-to-one comparison showed that most individual grid cells of ECHAM5 and CRU deviate between $10 \%$ and $20 \%$ from each other, whereas APHRODITE show mainly up to $60 \%(\approx 400 \mathrm{~mm})$ lower precipitation amount

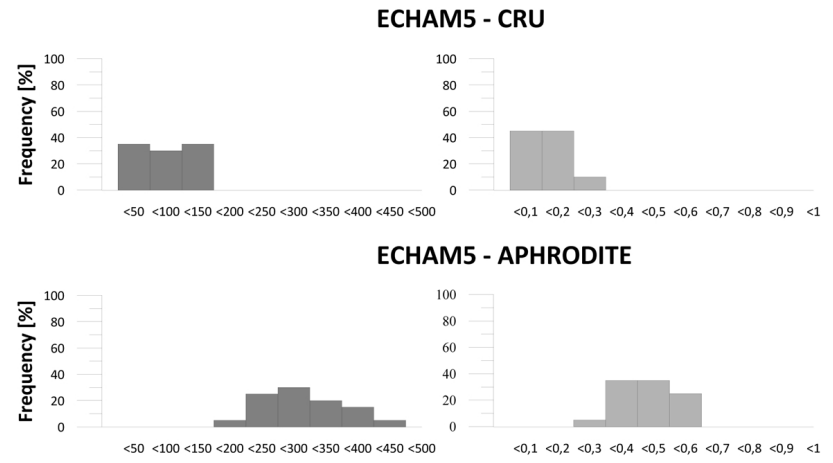

CRU - APHRODITE

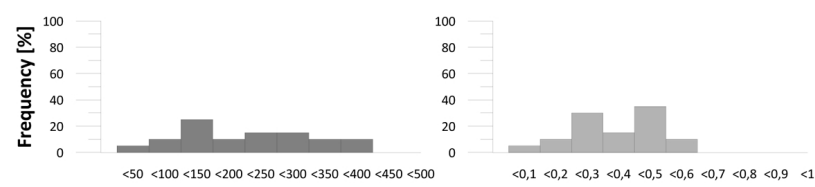

TRMM - APHRODITE

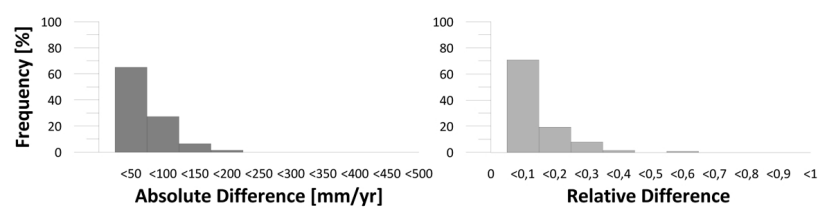

Fig. 6. Frequency distribution of the absolute and relative differences in mean precipitation from ECHAM5 and CRU, ECHAM5 and APHRODITE and CRU and APHRODITE for 1981-2004 and TRMM and APHRODITE for 1999-2007.

compared to ECHAM5 and CRU (Fig. 6). In consideration of the classified mean annual precipitation by Leber et al. (1995) the precipitation of ECHAM5 and CRU data seems to be overestimated particularly in the drier part (north of the Nyainqentanglha Mountains). On the other hand, APHRODITE appears to underestimate precipitation over the mountain range, since the grid resolution of $0.5^{\circ}$ is too coarse to represent orographic precipitation.

The results of the spatio-temporal analysis of the detected trends in the single grid cells are shown in Fig. 7. In general, the ECHAM5 precipitation data set did not show a significant trend in any of the grid cells during the entire period, which is in accordance with the station in the north-western part, but in disagreement with the highly significant increasing trend ( $p=95 \%)$ detected for stations in the eastern and southern part. On the other hand, this positive trend of precipitation in the east and south is reproduced by the data of CRU and APHRODITE.

\section{Comparison between APHRODITE and TRMM for 1999-2007}

Figure 8 reveals that the precipitation data of APHRODITE and TRMM, both based on a $0.25^{\circ}$ latitude-longitude grid, show a similar spatial pattern with highest precipitation values in southeast corresponding to the regional precipitation 
Table 6. Statistical analysis results for precipitation data of ECHAM5, CRU and APHRODITE for the period 1981-2004.

\begin{tabular}{|c|c|c|c|c|c|c|c|c|c|}
\hline \multirow{4}{*}{ Mean } & \multicolumn{9}{|c|}{ Precipitation [mm] } \\
\hline & \multicolumn{3}{|c|}{ ECHAM5 } & \multicolumn{3}{|c|}{ CRU } & \multicolumn{3}{|c|}{ APHRODITE } \\
\hline & Annual & Nov-Apr & May-Oct & Annual & Nov-Apr & May-Oct & Annual & Nov-Apr & May-Oct \\
\hline & 661 & 78 & 581 & 581 & 26 & 555 & 359 & 19 & 340 \\
\hline \multirow{2}{*}{ Mean Difference } & \multicolumn{3}{|c|}{ ECHAM5-CRU } & \multicolumn{3}{|c|}{ ECHAM5-APHRODITE } & \multicolumn{3}{|c|}{ CRU-APHRODITE } \\
\hline & Annual & Nov-Apr & May-Oct & Annual & Nov-Apr & May-Oct & Annual & Nov-Apr & May-Oct \\
\hline Absolute difference & 81 & 52 & 33 & 303 & 59 & 241 & 222 & 7 & 215 \\
\hline Relative difference & 0.12 & 0.67 & 0.06 & 0.46 & 0.76 & 0.41 & 0.38 & 0.28 & 0.39 \\
\hline
\end{tabular}
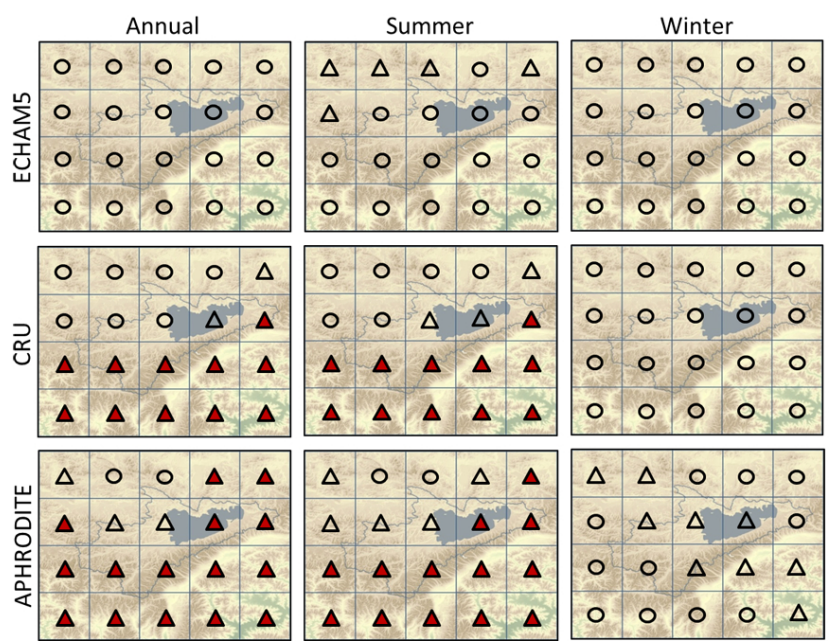

Fig. 7. Mann-Kendall trend test results for annual, summer and winter precipitation of ECHAM5 (top), CRU (middle) and APHRODITE (bottom) for the period 1981-2004 $(\triangle /$ red $\triangle=$ significant/highly significant increasing trend with $p=80 \% / 95 \%$; $=$ no significant trend).
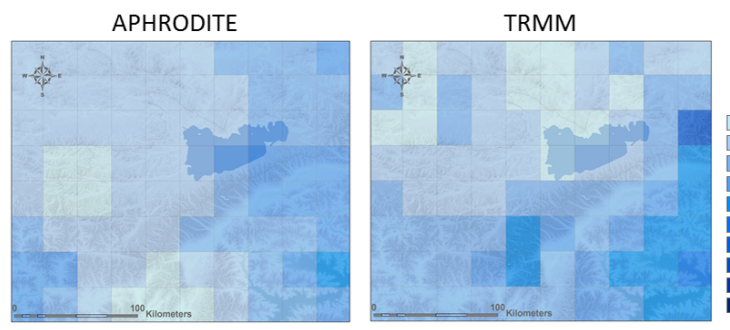

Fig. 8. Comparison of annual mean precipitation data of APHRODITE and TRMM for the period 1999-2007.

pattern by Leber et al. (1995). However, the resolution of $0.25^{\circ}$ is still not able to capture the orographic effects of the Nyainqentanglha Mountains.

The comparison of the precipitation spatially averaged for all grid cells for the entire year and the single seasonal pe- riods suggests that APHRODITE and TRMM correlate in both magnitude and seasonality (Table 7). The low mean absolute differences result in low mean relative differences of less than $10 \%$ for the entire year and for the summer period (Table 7). Because of the low precipitation amounts during winter a large relative difference of $40 \%$ was calculated. The one-to-one grid comparison (Fig. 6) showed that the single grid cells mostly differ by a value of around $50 \mathrm{~mm}$, i.e. $10 \%$. The TRMM values are slightly higher, especially in the south-eastern part (Fig. 8).

\section{Conclusions and outlook}

The analysis and assessment of input data is a crucial processing step in environmental modelling. Especially hydrological modelling in data-sparse regions like the Nam Co basin requires a good knowledge of the uncertainty of climate variables to ensure reliable model assessments. In this study, long-term and spatially distributed time series of temperature and precipitation derived from both ground measurements and global and regional climate modelling were compared to evaluate data uncertainties. The comparative data evaluation suggests that temperature data show a good agreement between all data sets, but of considerable disparities for precipitation data. Spatial and temporal deviations between various precipitation gridded data sets were found showing seasonal differences in the magnitude of rainfall up to $76 \%$ (especially high relative differences in dry winter seasons), but also contrary spatial pattern. In general, the regional data set of APHRODITE showed the best agreement with ground observations and a high accordance with TRMM.

This study also demonstrates that the grid resolution of $0.5^{\circ}$ and $0.25^{\circ}$ is too coarse to capture topographic and orographic effects in mountainous areas, because orographic precipitation which is an important source for water budget calculations is hardly represented. A further limitation by using coarse gridded data sets to drive hydrological models is that processes such as snow accumulation and melting cannot be simulated sufficiently, since the temperature 
Table 7. Statistical analysis results for precipitation data of APHRODITE and TRMM for the period 1999-2007.

\begin{tabular}{|c|c|c|c|c|c|c|}
\hline \multirow{4}{*}{ Mean } & \multicolumn{6}{|c|}{ Precipitation [mm] } \\
\hline & \multicolumn{3}{|c|}{ APHRODITE } & \multicolumn{3}{|c|}{ TRMM } \\
\hline & Annual & Nov-Apr & May-Oct & Annual & Nov-Apr & May-Oct \\
\hline & 404 & 20 & 384 & 428 & 34 & 394 \\
\hline \multirow{2}{*}{ Mean Difference } & \multicolumn{6}{|c|}{ APHRODITE - TRMM } \\
\hline & \multicolumn{2}{|c|}{ Annual } & \multicolumn{2}{|c|}{ Nov-Apr } & \multicolumn{2}{|c|}{ May-Oct } \\
\hline Absolute difference & \multicolumn{2}{|c|}{24} & \multicolumn{2}{|c|}{14} & \multicolumn{2}{|c|}{10} \\
\hline Relative difference & \multicolumn{2}{|c|}{0.06} & \multicolumn{2}{|c|}{0.4} & \multicolumn{2}{|c|}{0.03} \\
\hline
\end{tabular}

gradient in complex terrain is not reflected. To overcome these limitations, the downscaling of gridded climate data with tools such as SCALMET (Scaling Meteorological variables) (Marke, 2008) is a valid strategy to better reproduce varying climate conditions with terrain elevation more realistically. To address difficulties in downscaling precipitation estimations in data-scarce regions, Maussion et al. (2011) has shown that numerical weather prediction (NWP) models, especially the Weather Research and Forecasting (WRF) model, can be successfully applied to provide precipitation data of high spatial (up to $2 \mathrm{~km}$ ) and temporal resolution (daily, hourly). The study of Maussion et al. (2011) also highlights that in high-mountainous areas the accurate quantification of precipitation being influenced by orographic effects remains unsolved as long as reliable ground observations are missing. However, downscaled precipitation data which are expected to offer reliable input data for long-term hydrological modelling in river basins at the Tibetan Plateau will be tested against data provided by this study and evaluated regarding its potential for distributed hydrological modelling in data-scarce regions in future studies.

Acknowledgements. This work is funded by the DFG Priority Programme 1372 TiP - Tibetan Plateau: Formation-ClimateEcosystem.

Edited by: R. Ludwig, K. Schulz, and M. Disse

Reviewed by: two anonymous referees

\section{References}

Bian, D., Bianba, C., Li, L., Wang, W., and Zhaxi, Y.: The response of lake change to climate fluctuation in north QinghaiTibet Plateau in last 30 years, J. Geogr. Sciences, 19, 131-142, 2009.

Burn, D. H. and Elnur, M. A. H.: Detection of hydrologic trends and variability, J. Hydrol., 255, 107-122, 2002.

Chinese Acadamy of Sciences (CAS): Scientific working group on the Qinghai-Tibet Plateau: The climate of Xizang. The series of the scientific expedition to the Qinghai-Xizang Plateau, Beijing, 304 pp., 1984.

Ding, Y., Liu, S., Ye, B., and Zhao, L.: Climatic implications on variations of lakes in the cold and arid regions of China during the recent 50 years, Journal of Glaciology and Geocryology, 28(5), 623-632, 2006.

Dobler, A., Yaoming, M., Sharma, N., Kienberger, S., and Ahrens, B.: Regional climate projections in two alpine river basins: Upper Danube and Upper Brahmaputra, Adv. Sci. Res., 7, 11-20, doi:10.5194/asr-7-11-2011, 2011.

Eriksson, M., Xu, J., Shrestha, A., Vaidya, R. S. N., and Sandstrom, K.: The changing Himalayas: impact of climate change on water resources and livelihoods in the greater Himalayas, ICIMOD, Kathmandu, 2009.

Fekete, M. and Vörösmarty, C. J.: Uncertainties in precipitation and their impacts on runoff estimates, J. Climate, 17, 294-304, 2003.

Hipel, K. W. and McLeod, A. I: Time series modelling of water resources and environmental systems, Amsterdam, Netherlands, 2005.

Huffman, G. J., Adler, R. F., Bolvin, D. T., Gu, G., Nelkin, E. J., Bowman, K .P., Hong, Y., Stocker, E. F., and Wolff, D. B.: The TRMM multi-satellite precipitation analysis: Quasi-global, multi-year, combined-sensor precipitation estimates at fine scale, J. Hydrometeor., 8(1), 38-55, 2007.

Gourley, J. J. and Vieux, B. E.: A method for identifying sources of model uncertainty in rainfall-runoff simulations, J. Hydrol., 327, 68-80, 2006

Kang, S., Xu, Y., You, Q., Flügel, W.-A., Pepin, N., and Yao, T.: Review of climate and cryospheric change in the Tibetan Plateau, Environ. Res. Lett., 5, 015101 (8pp.), 2010.

Kendall, M. G.: Rank correlation measures, Charles Griffin, London, UK, 1975.

Krause, P., Biskop, S., Helmschrot, J., Flügel, W.-A., Kang, S., and Gao, T.: Hydrological system analysis and modelling of the Nam Co basin in Tibet, Adv. Geosci., 27, 29-36, doi:10.5194/adgeo27-29-2010, 2010.

Kropacek, J., Braun, A., Kang, S., Feng, C., Ye, Q., and Hochschild, V.: Analysis of lake level changes of Nam Co in Central Tibet by synergy of satellite altimetry and evaluation of optical satellite imagery, Int. J. Appl. Earth Obs. Geoinf., 17, 3-11, 2012.

Leber, D., Holawe, F., and Häusler, H.: Climatic classification of the Tibet Autonomous Region using multivariate statistical methods, GeoJournal, 37, 4, 451-473, 1995. 
Liu, J., Kang, S., Gong, T., and Lu, A.: Growth of a high-elevation large inland lake, associated with climate change and permafrost degradation in Tibet, Hydrol. Earth Syst. Sci., 14, 481-489, doi:10.5194/hess-14-481-2010, 2010.

Lu, A., Yao, T., Wang, L., Liu, S., and Guo, Z.: Study on the fluctuations of typical glaciers and lakes in the Tibetan Plateau using remote sensing (in Chinese), J. Glaciol. Geocryol., 6, 783-792, 2005.

Mann, H. B.: Non-parametric tests against trend, Econometrica, 13, 245-259, 1945.

Marke, T.: Development and Application of a Model Interface to couple Regional Climate Models with Land Surface Models for Climate Change Risk Assessment in the Upper Danube Watershed, Dissertation LMU München, available at: http://edoc.ub. uni-muenchen.de/9162/, München, 2008.

Maussion, F., Scherer, D., Finkelnburg, R., Richters, J., Yang, W., and Yao, T.: WRF simulation of a precipitation event over the Tibetan Plateau, China - an assessment using remote sensing and ground observations, Hydrol. Earth Syst. Sci., 15, 1795-1817, doi:10.5194/hess-15-1795-2011, 2011.

Mitchell, T. D. and Jones, P. D.: An improved method of constructing a database of monthly climate observations and associated high-resolution grids, Int. J. Climatol., 25, 693-712, 2005.
Prasch, M., Marke, T., Strasser, U., and Mauser, W.: Large scale integrated hydrological modelling of the impact of climate change on the water balance with DANUBIA, Adv. Sci. Res., 7, 61-70, doi:10.5194/asr-7-61-2011, 2011.

$\mathrm{Wu}, \mathrm{Y}$. and Zhu, L.: The response of lake-glacier variations to climate change in Nam Co catchment, central Tibetan Plateau, during 1970-2000, J. Geogr. Sci., 18, 177-189, 2008.

Yao, T., Li, Z., Yang, W., Guo, X. Zhu, L., Kang, S., Wu, Y., and Yu, W.: Glacier distribution and mass balance in the Yarlung Zangbo River and its influence on lakes, Chinese Science Bulletin, 55(20), 2072-2078, 2010.

Yatagai, A. O., Arakawa, K. ,Kamiguchi, H., Kawamoto, Nodzu, M. I., and Hamada, A.: A 44-year daily gridded precipitation dataset for Asia based on a dense network of rain gauges, SOLA, 5, 137140, 2009.

Ye, Q., Yao, T., and Chen, F.: Response of glacier and lake covariations to climate change in Mapam Yumco basin on Tibetan Plateau during 1974-2003, Journal of China University of Geosciences, 19(2), 135-145, 2008.

Zhu, L., Xie, M., and Wu, Y.: Quantitative analysis of lake area variations and the influence factors from 1971 to 2004 in the Nam Co basin of the Tibetan Plateau, Chinese Science Bulletin, 55(13), 1294-1303, 2010. 